\title{
Corn Crop Performance in Different Levels of Defoliation
}

\author{
Wanderley Lulu Gaias ${ }^{1}$, Eduardo Rodrigo Gibbert ${ }^{1}$, Lana Paola da Silva Chidichima ${ }^{1}$, Camila Hendges ${ }^{2}$ \\ $\&$ Alexandre Luis Muller ${ }^{1}$ \\ ${ }^{1}$ Pontifícia Universidade Católica do Paraná, Paraná, Brazil \\ ${ }^{2}$ Universidade Estadual do Oeste do Paraná, Paraná, Brazil \\ Correspondence: Lana Paola da Silva Chidichima, Pontifícia Universidade Católica do Paraná, Paraná, Brazil. \\ E-mail: lana_pchidichima@hotmail.com
}

Received: October 5, 2017

Accepted: December 3, 2017 Online Published: December 15, 2017

doi:10.5539/jas.v10n1p354

URL: https://doi.org/10.5539/jas.v10n1p354

\begin{abstract}
The aim of this work was to evaluate the effect of the yield and morphological components of the maize crop according to different levels of defoliation in the phenological stages of the crop. The experimental design was a randomized block with 7 treatments and 4 replicates. The treatments were: control without defoliation (SD), removal of two leaves (2L-V4) and four leaves (4L-V4) in the V4 stage, removal of the leaves of the lower third (LT-VT), removal of the middle third (MT-VT), removal of the upper third (UT-VT) and total removal (SF-VT) of the leaves in the VT stage. Plant height and spike insertion, number of grains, number of rows, grains per rows, one thousand grain mass and yield were assessed. Plants with total leaf removal had the lowest rates in all aspects evaluated. The number of rows, kernels per row and kernel per spike showed little or no variation in the treatments with partial defoliation. The treatments with removal at the middle and upper third had the lowest values for the analyzed variables when compared to the plants with partial defoliation. The results of this work indicate that the defoliation process can damage the corn yield performance.
\end{abstract}

Keywords: Zea maiz, reduction of leaf area, morphology

\section{Introduction}

Corn (Zea mays L.), is one of the most cultivated crops in the world, making it the second most produced grain on the planet. World production of corn in the 2015/2016 crop was of 959 million tons, with a production outlook for the 2016/2017 crop of 1.03 billion tons. In this context, Brazil is the third largest producer of the grain, with 84 million tons (Fiesp, 2016).

The corn crop is characterized by the high capacity of radiant energy conversion in biomass production. Each seed has a mass of approximately 0.26 grams, and in the course of its cycle multiplies the initial weight by approximately 1000 times, producing from 180 to 250 grams of grains, and generating a plant with total biomass of 800 to 1200 grams (Fancelli, 2010).

The amount of leaf area of a crop defines its photosynthetic potential and this variable depends on the size, number and stage of development of the plants. In the plant cycle, the leaf area grows until reaching a maximum, where it remains for a certain time and with the senescence of the older leaves begins to decline in the more advanced stages of the development of the plants. Thus, the equation between leaf volume, leaf exposure time and photosynthesis, and plant production in a direct ratio between these factors is evident (Alvim et al., 1999).

In order for plants to efficiently express their genetic potential in productivity, it is important that they acquire the highest leaf area index in the shortest time possible, so that the interception and efficient use of this energy is maximized. The potentiation of photosynthesis improves the distribution of assimilates in the ideal proportion for the formation of leaves, stems, roots and reproductive structures, keeping these processes at the lowest possible cost for the plant (Loomis \& Amthor, 2001).

The productive potential of the maize crop is defined from the V4 and V5 stages, where the floral differentiation occurs, giving rise to the tassel and also to the spike, besides the differentiation of all the leaves. In the V8 stage, the number of rows of grains is defined and then the number of ova per row (Rezende et al., 2015). Foliar damage at these stages may cause variations in agronomic characteristics affecting productivity as well as the physiological quality of the grains (Pereira et al., 2012). 
The decrease in leaf area occurs due to damage caused to the leaves of maize plants. These damages may be related to drastic climatic phenomena, such as the occurrence of frost and hail (Lima, 2010). However, the greatest difficulties related to defoliation in the production of high-investment hybrids are usually the damages caused by chewing insects, and in this context the caterpillar of the corn cartridge Spodoptera frugiperda is highlighted (Lourenção \& Fernandes, 2013).

The pest attack contributes to the entry of pathogens, causing lesions in the upper parts of the leaves, compromising the leaf area (Pinto, 2005). The early loss of leaves restricts the uptake of light and the transport of photo-assimilates to the reserve tissues, compromising the development of grains (Bortolini \& Gheller, 2012).

Therefore, in order to measure foliar damages caused by several factors that could cause crop damage, this study aimed to evaluate the effect of maize crop productivity and morphological components according to different levels of defoliation in the phenological stages of culture.

\section{Material and Methods}

The experiment was carried out in the city of Toledo, Paraná, Brazil. The experiment site is located at $24^{\circ} 43^{\prime} 17.81^{\prime \prime} \mathrm{S}$ and $53^{\circ} 46^{\prime} 45.54^{\prime \prime} \mathrm{W}$, at an altitude of $540 \mathrm{~m}$ above sea level. The local climate is classified according to Koppen type $\mathrm{Cfa}$, subtropical with well distributed rains during the year and hot summers between 28 and $29{ }^{\circ} \mathrm{C}$, with an average annual temperature varying between 22 and $23{ }^{\circ} \mathrm{C}$. The rainfall total annual average for the region varies from 1.600 to $1.800 \mathrm{~mm}$ (Iapar, 2006). The soil of the experimental area is classified as Eutroferric Red Latosol of very clayey texture (Embrapa, 2013).

The experimental design was a randomized complete block (RCBD), with 7 treatments and 4 replicates, being: control without defoliation (WD), removal of two leaves (2L-V4) and four leaves (4L-V4) at the V4 stage, removal of the lower third(LT-VT), removal of leaves from the medium third (MT-VT), removal of leaves from the upper third (UT-VT) and total leaf removal (SL-VT) at the VT stage.

The experimental plots were composed of 6 rows with spacing between rows of $0.45 \mathrm{~m}$ by 6 meters in length, totaling $16.2 \mathrm{~m}^{2}$ of area. Before sowing the maize crop, the area was desiccated with glyphosate at a dose of 2.8 $\mathrm{L} \mathrm{ha}^{-1}$, aiming at greater sowing and favoring the initial development of maize.

The experiment was implemented on February 2016, marking the lines with the aid of the sowing in the system of minimum cultivation, where the predecessor crop was soybean. The hybrid used was CD3612PW, which has a medium cycle of 130 days with some grain characteristics, such as hadness, lodging resistance, mean spike insertion height of $105 \mathrm{~cm}$ and average plant height of $220 \mathrm{~cm}$, the hybrid recommendation was population density of 60 thousand ha $^{-1}$ plants.

The sowing was carried out manually with the help of the precision ratchet and two seeds were placed per pit. After the emergence, the thinning of the plants in the V2 stage was carried out, $350 \mathrm{~kg} \mathrm{ha}^{-1}$ of the NPK 08-20-20 formulation was used in the base fertilization, and afterwards the cover fertilization was applied at a dosage of 75 $\mathrm{kg} \mathrm{ha}^{-1}$, carried out in the phenological stage V6.

During the development of the crop, it was necessary to perform the pest control, due to the high presence of Spodoptera frugiperda, applying the physiological insecticide of the chemical group Benzoylurea, in the dosage of $300 \mathrm{~mL} \mathrm{ha}^{-1}$ in the phenological stage V3. For weed management, the control was carried out by manual weeding at the phenological stage V2.

When the crop showed complete maturation at 135 days after sowing (DAS), the plants were harvested manually in a useful area of $9 \mathrm{~m}^{2}$ (4 lines $\times 5$ meters), discarding the lines of the border and 0.5 meters of each side, to avoid the border effect in the variables to be analyzed.

The evaluations were carried out from the maturation of the plants, where 10 plants were randomly collected within the useful area of the plot, being determined the height of plants, the measurement was carried out with the aid of a scale graded in $\mathrm{cm}$, having as references the surface from the soil to the apex of the plant; the height of the insertion of the spike with the aid of a scale graded in $\mathrm{cm}$ and taking as reference the soil surface to the base of the spike and, stem diameter being measured with the aid of a digital caliper in millimeters, the measurement being carried out at about $10 \mathrm{~cm}$ above the soil surface.

After the measurements related to plant morphology were carried out, the evaluations of the productive variables were carried out. For this, 10 spikes were harvested at random within the useful area, which were manually destemmed to determine the following characteristics: number of rows of grains, performed in the middle third of the spikes where the rows were completely differentiated and formed by manual counting; number of grains per row performed by direct counting of the grains contained in a completely differentiated row from the base to 
the apex of the spike; number of grains per spike determined from the manual threshing of the spikes, with subsequent counting of the grains present in the spike.

Finally, we evaluated the productivity of the spikes harvested in the useful area, which were submitted to a mechanical track, afterwards weighing the grains in a $0.001 \mathrm{~g}$ precision scale, obtaining the productivity per plot and extrapolating the values for productivity per hectare, performing the correction of humidity to $13 \%$. It was also evaluated the thousand grain weight (TGW), and with the grains obtained in the productivity analysis, 8 samples of 100 grains were separated, weighed in a precision scale of $0.001 \mathrm{~g}$ with the result extrapolated to the amount of one thousand grains.

After the data were collected, they were tabulated and submitted to analysis of variance using the $\mathrm{F}(p<0.05)$ test, using the statistical program Sisvar (Ferreira, 2011), and when the value of $f$ was significant, the averages were submitted to the Tukey test at $5 \%$ error probability.

\section{Results and Discussion}

For the variables related to plant morphology, spike insertion, plant height and stem diameter, variance analyzes showed significant differences $(p<0.05)$ when evaluating different levels of defoliation in corn crop (Table 1$)$.

Table 1. Average spike insertion, plant height and stem diameter, submitted to different levels of defoliation in maize cultivated in the city of Toledo, Paraná, Brazil

\begin{tabular}{llll}
\hline Defoliation & Plants height $(\mathrm{cm})$ & Spike Insertion $(\mathrm{cm})$ & Stem diameter $(\mathrm{mm})$ \\
\hline SD & $192 \mathrm{a}$ & $104 \mathrm{a}$ & $22.0 \mathrm{a}$ \\
2F-V4 & $186 \mathrm{ab}$ & $102 \mathrm{a}$ & $21.5 \mathrm{ab}$ \\
4F-V4 & $186 \mathrm{ab}$ & $102 \mathrm{a}$ & $21.5 \mathrm{ab}$ \\
TI-VT & $185 \mathrm{ab}$ & $102 \mathrm{a}$ & $21.7 \mathrm{ab}$ \\
TS-VT & $186 \mathrm{ab}$ & $102 \mathrm{a}$ & $21.2 \mathrm{~b}$ \\
TM-VT & $169 \mathrm{bc}$ & $94 \mathrm{~b}$ & $19.8 \mathrm{c}$ \\
SF-VT & $163 \mathrm{c}$ & $94 \mathrm{~b}$ & $19,5 \mathrm{c}$ \\
\hline Average & 175 & 100 & 20.2 \\
CV $(\%)$ & 3.31 & 1.88 & 1.35 \\
\hline
\end{tabular}

Note. ${ }^{1}$ Means followed by the same letter in the column do not differ at the $5 \%$ level of error probability by the Tukey test. ${ }^{2}$ WD (Without defoliation), 2L-V4 (Removal of two sheets in the V4 stage), 4L-V4 (Removal of four sheets in the V4 stage), LT-VT (Removal of the leaves of the lower third of the plant in the VT stage), UT-VT (Removal of the leaves of the upper third of the plant in the VT stage), MT-VT (Removal of the leaves of the middle third of the plant in the VT stage), SF-VT (Total removal of plant leaves in the VT stage). ${ }^{3} 10$ replicates per variable were used.

Considering the variable insertion of spikes, the plants that were not defoliated presented the best performance, with $104 \mathrm{~cm}$. Plants in the treatments performed with the withdrawal of 2 leaves and 4 leaves in the V4 stage, as well as the plants that removed the leaves of the upper third and the leaves of the lower third did not differ from the control. However, the plants in the treatments with total removal of the leaves and the leaves of the middle third did not differ among themselves, presenting height of insertion of spikes inferior to the other plants of the treatments compared.

For the variable plants height, the ones that obtained the best results were in the treatment without defoliation with $192 \mathrm{~cm}$, however, it showed to be similar to the plants in the treatments of the removal of two and four leaves in the V4 stage, as well as the plants that had the upper third and lower third removed. However, the plants in the treatments with total leaved removal and removal of the leaves of the middle third, showed the lowest heights of plants compared to the plants of the other treatments. Resende et al. (2014) found that, in general, the greater the amount of leaf area removed, the lower was the plant height and the height of spike insertion.

For stem diameter, the best performance was of the plants in the treatment without defoliation. Sequentially, the plants in the treatments with removal of 2 leaves and of 4 leaves in the V4 stage and the removal of the leaves of the lower third, obtained results similar to the one of the control, not having any difference among each other. In turn, the stems of the plants with the smallest diameters were found by means of the treatments with the total 
removal of the leaves and removal of the leaves of the middle third, these presenting similar results among themselves.

Alvim et al. (2010), evaluating the effects of the defoliation performed in the R2 stage, obtained data that prove the source relationship that the stem exerts on the plants supplying metabolites in quantity capable of partially satisfy the demand of the plant even in conditions of severe defoliation, fact that explains the reduction of stem diameter thickness that occurs at the time of defoliation.

For the productivity components of number of rows per spike, grains per row and grain per ear, analysis of variance showed significant differences $(p<0.05)$, showing the lowest results when the plants were submitted to total defoliation, which did not present grain production by the spikes (Table 2).

Table 2. Average number of grains per row, number of rows per spike, number of grains per spike, submitted to different defoliation levels in corn cultivated in the city of Toledo, Paraná, Brazil

\begin{tabular}{llll}
\hline Defoliation & Grains per Rows & Spike Rows & Grains per Spike \\
\hline SD & $37 \mathrm{a}$ & $15.3 \mathrm{a}$ & $528.1 \mathrm{a}$ \\
2F-V4 & $37 \mathrm{a}$ & $15.7 \mathrm{a}$ & $515.5 \mathrm{a}$ \\
4F-V4 & $37 \mathrm{a}$ & $15.1 \mathrm{a}$ & $521.3 \mathrm{a}$ \\
TI-VT & $37 \mathrm{a}$ & $15.2 \mathrm{a}$ & $510.7 \mathrm{~b}$ \\
TS-VT & $35 \mathrm{a}$ & $14.8 \mathrm{a}$ & $474.2 \mathrm{~b}$ \\
TM-VT & $35 \mathrm{a}$ & $15.1 \mathrm{a}$ & $470.6 \mathrm{~b}$ \\
SF-VT & $0 \mathrm{~b}$ & $0 \mathrm{~b}$ & $0 \mathrm{c}$ \\
Average & 31.14 & 13.04 & 431.51 \\
CV $(\%)$ & 3.86 & 3.54 & 3.3 \\
\hline
\end{tabular}

Note. ${ }^{1}$ Means followed by the same letter in the column do not differ at the $5 \%$ level of error probability by Tukey test. ${ }^{2}$ WD (Without defoliation), 2L-V4 (Removal of two sheets in the V4 stage), 4L-V4 (Removal of four sheets in the V4 stage), LT-VT (Removal of the leaves of the lower third of the plant in the VT stage), UT-VT (Removal of the leaves of the upper third of the plant in the VT stage), MT-VT (Removal of the leaves of the middle third of the plant in the VT stage), SL-VT (Total removal of plant leaves in the VT stage). ${ }^{3} 10$ replicates per variable were used.

According to Ritchie et al. (2003), the total removal of leaves due to hail in the VT stage, causes total loss of production, corroborating the results obtained by the defoliation performed in the present study.

In a study conducted by Alvim et al. (2010), with different levels of defoliation in the R2 stage, they found that the treatments did not present significant differences among the number of grains per spike, which refers to the capacity of reallocation of the reserves contained mainly in the stem, ensuring that the plants achieve, although with lower mass, establish the grain formation in the normal way.

As well as in the other variables, the number of grains per spike obtained the lowest indices when the plants were submitted to the treatment of total removal of leaves, not obtaining grain yield. However, when the leaves of the middle and upper third were removed, the plants had the lowest indices, when compared to the plants that had the leaves removed in the V4 stage and those of the lower third, but still superior to the treatment of total removal of leaves. Romano (2005) emphasizes that the apical region of the corn ear is the most affected in grain development, when it is submitted to defoliation of the upper thirds of the plant.

For thousand grain weight (TGW) and productivity, the analysis of variance showed a significant difference ( $p<$ 0.05 ), as presented in Table 3. The plants in the treatment with total removal of leaves did not present grain production differing from the other treatments. Afterwards, the plants in the treatments with removal of the leaves of the middle and upper third presented inferior results for both TGW and productivity, being superior only to total defoliation. 
Table 3. Results from thousand grain weight and productivity, submitted to defoliation levels in corn cultivated in the municipality of Toledo, Paraná, Brazil

\begin{tabular}{lll}
\hline Defoliation & TGW $(\mathrm{g})$ & Productivity $\left(\mathrm{kg} \mathrm{ha}^{-1}\right)$ \\
\hline SD & $337.5 \mathrm{a}$ & $7766.20 \mathrm{a}$ \\
2F-V4 & $325.0 \mathrm{ab}$ & $7762.15 \mathrm{a}$ \\
4F-V4 & $312.5 \mathrm{~b}$ & $7662.03 \mathrm{a}$ \\
TI-VT & $318,7 \mathrm{~b}$ & $7030.09 \mathrm{~b}$ \\
TS-VT & $293,7 \mathrm{c}$ & $5995.37 \mathrm{c}$ \\
TM-VT & $287,5 \mathrm{c}$ & $5380.78 \mathrm{~d}$ \\
SF-VT & $0.0 \mathrm{~d}$ & $0.00 \mathrm{e}$ \\
\hline Average & 267,8 & 5942.37 \\
CV $(\%)$ & 2.82 & 4.16 \\
\hline
\end{tabular}

Note. ${ }^{1}$ Means followed by the same letter in the column do not differ at the $5 \%$ level of error probability by the Tukey test. ${ }^{2}$ WD (Without defoliation), 2L-V4 (Removal of two sheets in the V4 stage), 4L-V4 (Removal of four sheets in the V4 stage), LT-VT (Removal of the leaves of the lower third of the plant in the VT stage), UT-VT (Removal of the leaves of the upper third of the plant in the VT stage), MT-VT (Removal of the leaves of the middle third of the plant in the VT stage), SL-VT (Total removal of plant leaves in the VT stage). ${ }^{3} 4$ replicates per variable were used.

Camacho et al. (1995) indicate that approximately half of the carbohydrates present in the grains originate from the leaves that are in the upper third of the plant, and it is evident that the greatest impacts on TGW were caused when the leaves were removed in the middle and upper thirds. The plants with defoliation in the lower third, and of two and four leaves in V4 stage did not differ among themselves, but TGW was lower than that of the control that obtained the highest weight $(337.5 \mathrm{~g})$, which, in turn, did not differ from that of plants with two leaves removed in V4.

For the productivity, the plants that did not suffer defoliation stood out with $7766.20 \mathrm{~kg} \mathrm{ha}^{-1}$, however, this result did not differ from the other plants that had the leaves removed in V4. The level of production obtained through the above mentioned treatments is considered satisfactory, and the average productivity in the west of Paraná in the 2016/2016 season was $5.091 \mathrm{~kg} \mathrm{ha}^{-1}$ (Conab, 2017).

Resende et al. (2014) found that even with the withdrawal of 4 leaves in the initial stages of the crop development (V4), the loss of productivity is minimal, a similar result is found in the present study where there was no difference, evidencing that the crop has wide capacity of recovery when under stress in the early stages. Unlike Lima and Assmann (2015), they reported that when evaluating the defoliation caused by Spodoptera frugiperda in corn, there was a greater loss of productivity in the early stages, accentuating in the V6 stage.

If the removal of leaves from the lower third, the loss of productivity in relation to the plants that did not suffer defoliation was 9.5\%, a similar result was found by Romano (2005), who evaluated the plants submitted to defoliation of the lower third and obtained a reduction of $4.4 \%$ in productivity in relation to the control.

The plants that had leaves removal in the upper and middle third, had losses of $23 \%$ and $30.7 \%$ respectively, in relation to the plants without defoliation. This variation can be explained by the fact that the leaves inserted in the various stem positions are responsible for the supply of photoassimilates to certain parts of the plant. In this way, the leaves of the lower third are responsible for the supply that the roots need, while the leaves of the middle and upper third are responsible for the upper organs of the plant, acting on the spike and grain formation (Brito et al., 2011).

The plants that had the total removal of the leaves in the stage of VT did not obtain spike formation. Alvim et al. (2010) obtained contrasting results with a 79\% lower yield than the control when carrying out the total removal of leaves, but the phenological stage of the crop was in R2, in other words, the formation and pollination of the ears had already occurred.

In the corn crop, the period covered between the vomiting (VT) and that of the milky grains (R3) is considered critical for the crop, and it is during this period the plant needs maximum photosynthetic capacity, being evident that any factor that damages the area foliar, as the occurrence of diseases directly influences the process of grain production and consequently in crop productivity (Cruz et al., 2011). 


\section{Conclusion}

The total defoliation of plants in the VT stage causes no spike formation, besides reducing plant height and spike insertion in the maize crop. Leaf withdrawal in the early stages of the crop does not compromise the productivity components. Depletion levels in the VT stage interfere with crop productivity.

\section{References}

Alvim, K. R. T., Brito, C. H., Brandão, A. M., Gomes, L. S., \& Lopes, M. T. G. (2010). Quantificação da área foliar e efeito da desfolha em componentes de produção de milho. Ciência Rural, 40(5), 1017-1022. https://doi.org/10.1590/S0103-84782010000500003

Bortolini, A. M. M., \& Gheller, J. A. (2012). Aplicação de diferentes fungicidas no controle de doenças foliares na cultura do milho em relação à produtividade. Revista Brasileira de Energias Renováveis, 1, 109-121. https://doi.org/10.5380/rber.v1i1.33755

Brito, C. H., Silveira, D. L., Brandão, A. M., Gomes, L. S., \& Lopes, M. T. G. (2011). Redução de área foliar em milho em região tropical no Brasil e os efeitos em caracteres agronômicos. Interciencia, 36(4), 291-295.

Camacho, R. G., Garrido, O., \& Lima, M. G. (1995). Caracterizacion de nueve genotipos de maiz (Zea mays L.) en relacion a area foliar y coeficiente de extincion de luz. Scientia Agrícola, 52(2), 294-298. https://doi.org/10.1590/S0103-90161995000200015

Conab (Companhia Nacional de Abastecimento). (2017). Levantamento de safra 2016/2017. Retrieved from http://www.conab.gov.br/OlalaCMS/uploads/arquivos/17_04_17_17_20_55_boletim_graos_abr_2017.pdf

Cruz, J. C., Magalhães, P. C.,Filho, I. A. P., \& Moreira, J. A. A. (2011). Milho: O produtor pergunta, a Embrapa responde. Brasília: Embrapa Informação Tecnológica.

Embrapa (Empresa Brasileira de Pesquisa Agropecuária). (2013). Sistema brasileiro de classificação de solos (2nd ed.). Rio de Janeiro: EMBRAPA Solos.

Fancelli, A. L. (2010). Fisiologia, nutrição e adubação do milho para alto rendimento. Piracicaba: ESALQ/USP.

Ferreira, D. F. (2011). Sisvar: A computer statistical analysis system. Ciência e Agrotecnologia, 35(6), 1039-1042. https://doi.org/10.1590/S1413-70542011000600001

Fiesp (Federação das Indústrias do Estado de São Paulo). (2016). Safra Mundial de Milho 2016/17. Retrieved from http://www.fiesp.com.br/indices-pesquisas-e-publicacoes/safra-mundial-de-milho-2/attachment/boleti m_milho_setembro2016

Iapar (Instituto Agronômico do Paraná). (2006). Cartas Climáticas do Paraná. Retrieved from https://www.scienceopen.com/document?vid=5d6464d9-02da-40b2-bbd3-b81eb72555e0

Lima, L. G., \& Assmann, E. J. (2015). Desfolha causada pela Spodoptera frugipera em milho com diferentes biotecnologias. Revista Cultivando o Saber, Edição Especial, 56-66.

Lima, T. G. (2010). Consequências da remoção do limbo foliar em diferentes estados reprodutivos da cultura do milho em duas épocas de semeadura. Bragantina, 69(3), 563-570. https://doi.org/10.1590/S0006-8705201 0000300007

Loomis, R. S., \& Amthor, J. S. (1999). Yield potential, plant assimilatory capacity, and metabolic efficiencies. Crop Science, 39, 1584-1596. https://doi.org/10.2135/cropsci1999.3961584x

Lourenção, A. L. F., \& Fernandes, M. G. (2013). Avaliação do Milho Bt Cry1Ab e Cry1F no controle de Spodoptera frugiperda (J. E. Smith, 1797) (Lepidoptera: Noctuidae) em condições de campo. Científica, 41(2), 164-188. https://doi.org/10.15361/1984-5529.2013v41n2p164-188

Pereira, M. J. R., Bonan, E. C. B., Garcia, A., Vasconcelos, R. L., Giacomo, K. S., \& Lima, M. F. (2012). Características morfoagronômicas do milho submetido a diferentes níveis de desfolha manual. Revista Ceres, 59(2), 200-205. https://doi.org/10.1590/S0034-737X2012000200008

Pinto, A. J. F. N. (2005). Grãos ardidos em milho. Sete Lagoas: Embrapa Milho e Sorgo, Circular Técnica no 66.

Resende, D. C., Mendes, S. M., Waquil, J. M., Duarte, J. O., \& Santos, F. A. (2014). Adoção da área de refúgio e manejo de resistência de insetos em milho Bt. Revista de Política Agrícola, 23(1), 119-128. 
Rezende, W. S., Brito, C. H., Brandão, A. F., Franco, J. F., Ferreira, M. V., \& Ferreira, A. S. (2015). Desenvolvimento e produtividade de grãos de milho submetido a níveis de desfolha. Revista Pesquisa Agropecuária Brasileira, 50(3), 203-209. https://doi.org/10.1590/S0100-204X2015000300003

Ritchie, S. W., Hanway, J. J., \& Benson, G. O. (2003). Como a planta de milho se desenvolve. Encarte de informações agronômicas $\mathrm{n}^{\circ}$ 103. K P Potafos, 103, 1-20. Retrieved from http://brasil.ipni.net/ipniweb/ region/brasil.nsf/0/DE02520B8765B8D683257AA0003C46A6/\$FILE/Encarte103.pdf

Romano, M. R. (2005). Desempenho fisiológico da cultura de milho com plantas de arquitetura contrastante: parâmetros para modelos de crescimento (Doctoral dissertation, Universidade de São Paulo, São Paulo, Brazil).

\section{Copyrights}

Copyright for this article is retained by the author(s), with first publication rights granted to the journal.

This is an open-access article distributed under the terms and conditions of the Creative Commons Attribution license (http://creativecommons.org/licenses/by/4.0/). 